\title{
Applying no-depletion equilibrium sampling and full-depletion bioaccessibility extraction to 35 historically polycyclic aromatic hydrocarbon contaminated soils
}

Bartolomé, Nora; Hilber, Isabel; Sosa, Dayana; Schulin, Rainer; Mayer, Philipp; Bucheli, Thomas D.

Published in:

Chemosphere

Link to article, DOI:

10.1016/j.chemosphere.2018.01.159

Publication date:

2018

Document Version

Peer reviewed version

Link back to DTU Orbit

Citation (APA):

Bartolomé, N., Hilber, I., Sosa, D., Schulin, R., Mayer, P., \& Bucheli, T. D. (2018). Applying no-depletion equilibrium sampling and full-depletion bioaccessibility extraction to 35 historically polycyclic aromatic hydrocarbon contaminated soils. Chemosphere, 199, 409-416.

https://doi.org/10.1016/j.chemosphere.2018.01.159

\section{General rights}

Copyright and moral rights for the publications made accessible in the public portal are retained by the authors and/or other copyright owners and it is a condition of accessing publications that users recognise and abide by the legal requirements associated with these rights.

- Users may download and print one copy of any publication from the public portal for the purpose of private study or research.

- You may not further distribute the material or use it for any profit-making activity or commercial gain

- You may freely distribute the URL identifying the publication in the public portal 


\section{Accepted Manuscript}

Applying no-depletion equilibrium sampling and full-depletion bioaccessibility extraction to 35 historically polycyclic aromatic hydrocarbon contaminated soils

Nora Bartolomé, Isabel Hilber, Dayana Sosa, Rainer Schulin, Philipp Mayer, Thomas D. Bucheli

PII: S0045-6535(18)30176-0

DOI: 10.1016/j.chemosphere.2018.01.159

Reference: $\quad$ CHEM 20740

To appear in: $\quad E C S N$

Received Date: 8 November 2017

Revised Date: 25 January 2018

Accepted Date: 28 January 2018

Please cite this article as: Bartolomé, N., Hilber, I., Sosa, D., Schulin, R., Mayer, P., Bucheli, T.D., Applying no-depletion equilibrium sampling and full-depletion bioaccessibility extraction to 35 historically polycyclic aromatic hydrocarbon contaminated soils, Chemosphere (2018), doi: 10.1016/ j.chemosphere.2018.01.159.

This is a PDF file of an unedited manuscript that has been accepted for publication. As a service to our customers we are providing this early version of the manuscript. The manuscript will undergo copyediting, typesetting, and review of the resulting proof before it is published in its final form. Please note that during the production process errors may be discovered which could affect the content, and all legal disclaimers that apply to the journal pertain. 

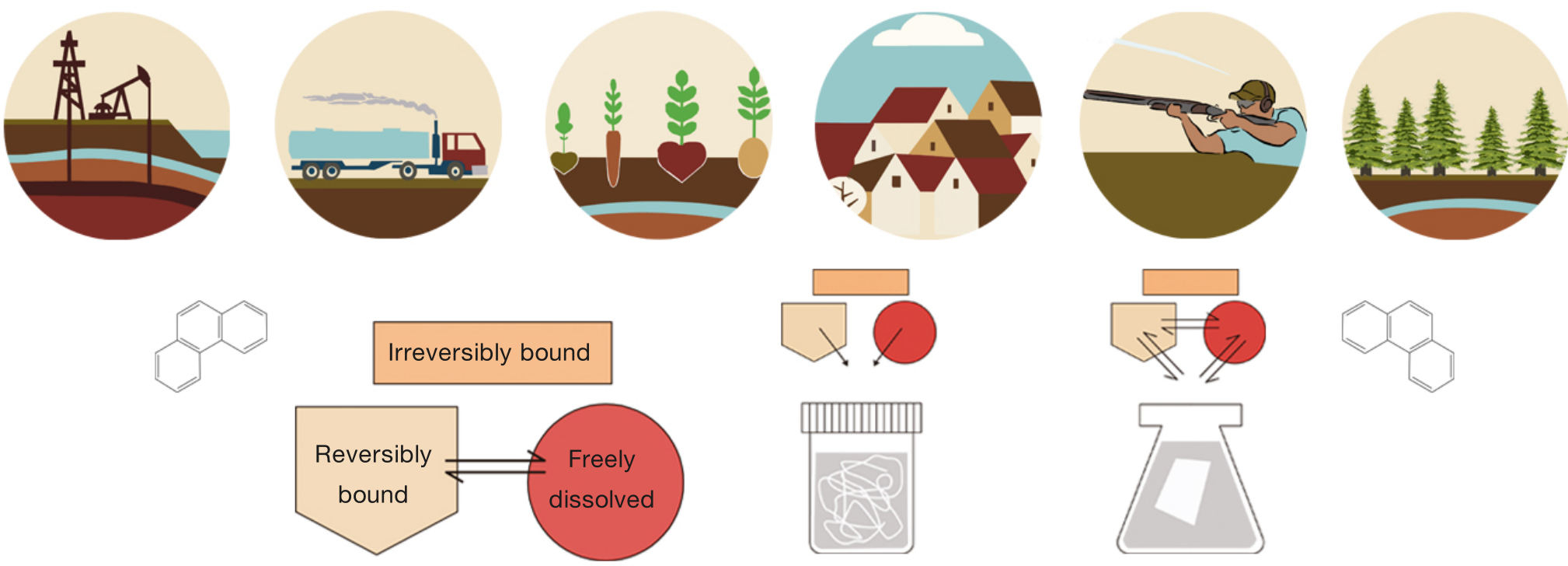

Accessible portion

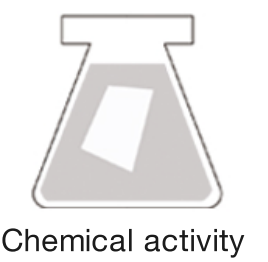




\section{$1 \quad$ Applying no-depletion equilibrium sampling and full-depletion}

2 bioaccessibility extraction to 35 historically polycyclic aromatic

4

5 Nora Bartolomé, ${ }^{\mathrm{a}, \mathrm{b}}$, Isabel Hilber ${ }^{\mathrm{a}}$, Dayana Sosa ${ }^{\mathrm{c}}$, Rainer Schulin ${ }^{\mathrm{b}}$, Philipp Mayer ${ }^{\mathrm{d}}$ and 6 Thomas D. Bucheli ${ }^{\mathrm{a}, *}$.

7

$8 \quad{ }^{a}$ Agroscope, Environmental Analytics, Reckenholzstrasse 191, 8046 Zurich, Switzerland

$9 \quad{ }^{\mathrm{b}}$ Department of Environmental System Science, ETH Zurich, 8093 Zurich, Switzerland

$10{ }^{\mathrm{c}}$ Centro Nacional de Sanidad Agropecuaria (CENSA), Apartado 10, CP 32700, San José de 11 las Lajas, Mayabeque, Cuba

$12{ }^{\mathrm{d}}$ Technical University of Denmark, DK - 2800 Kgs, Lyngby. Denmark 13

14 Corresponding author's e-mail: Thomas.bucheli@agroscope.admin.ch 15 
19

20

22

23

24

25

26

27

28

29

30

31

32

33

34

35

36

37

38

39

40

41

42

43

\section{Abstract}

Assessing the bioaccessibility of organic pollutants in contaminated soils is considered a complement to measurements of total concentrations in risk assessment and legislation. Consequently, methods for its quantification require validation with historically contaminated soils. In this study, 35 such soils were obtained from various locations in Switzerland and Cuba. They were exposed to different pollution sources (e.g., pyrogenic and petrogenic) at various distance (i.e., urban to rural) and were subject to different land use (e.g., urban gardening and forest). Passive equilibrium sampling with polyoxymethylene was used to determine freely dissolved concentrations $\left(\mathrm{C}_{\text {free }}\right)$ of polycyclic aromatic hydrocarbons (PAHs), while sorptive bioaccessibility extraction (SBE) with silicone rods was used to determine the bioaccessible PAH concentrations $\left(\mathrm{C}_{\text {bioacc }}\right)$ of these soils.

The organic carbon partitioning coefficients of the soils were highest for skeet soils, followed by traffic, urban garden and rural soils. Lowest values were obtained from soil exposed to petrogenic sources. Applicability of SBE to quantify $\mathrm{C}_{\text {bioacc }}$ was restricted by silicone rod sorption capacity, as expressed quantitatively by the Sorption Capacity Ratio (SCR); particularly for soils with very high $\mathrm{K}_{\mathrm{D}}$. The source of contamination determined bioaccessible fractions ( $f_{\text {bioacc }}$ ). The smallest $f_{\text {bioacc }}$ were obtained with skeet soils (15\%), followed by the pyrogenically influenced soils, rural soils, and finally, the petrogenically contaminated soil (71\%). In conclusion, we present the potential and limitations of the SBE method to quantify bioaccessibility in real soils. These results can be used for additional development of this and similar bioaccessibility methods to guarantee sufficient sorption capacity to obtain reliable results.

\section{Keywords}


44 Bioavailability, SBE, passive sampling, sink capacity, PAH, soil

45 Capsule

46 Freely dissolved concentrations and bioaccessible fractions of PAHs in soils depended

47 on pollutant source and site characteristics, while the sink capacity was limiting 48 during bioaccessibility extractions of soils with low PAH content and high $\mathrm{K}_{\mathrm{D}}$ values. 49

50 


\section{Introduction}

52 Regulatory guidelines for the assessment and treatment of soil contamination by

53

54 polycyclic aromatic hydrocarbons (PAHs) are still based on their total concentration in dry bulk soil as indicators of the potential exposure of soil-dwelling organisms, plants and humans (Regulation (EC) No 1907/2006 of the European Parliament and of the Council, 2006 ; Swiss Confederation, 2016). However, this criterion is increasingly disputed because it does not describe the pollutant fraction that is best linked to PAH exposure toxicity and mobility in soils (Reid et al., 2000a).

Recently, Ortega-Calvo et al. (2015) discussed the concept of "bioavailability" to organic soil contaminants and identified essential points that need to be accepted by environmental regulators before it can be incorporated into risk assessment frameworks. This requires the consistent use of the concept of "bioavailability", the establishment of corresponding operational standards and robust methods to quantify it. The concept of bioavailability comprises two parameters, both of which are valuable, valid and complementary to each other (Reichenberg and Mayer, 2006). The first is the chemical activity of a contaminant, that is closely linked to freely dissolved concentrations $\left(\mathrm{C}_{\text {free }}\right)$, e.g., in pore water and characterises the potential for partitioning and diffusion processes. It represents the readily available pollutant concentration, and is often called bioavailability. The second includes those molecules that are or can become available for interaction with biotic receptors. It includes the fraction of a contaminant that is freely dissolved plus the fraction that can become rapidly available through desorption from solid surfaces; this is called bioaccessible portion (Reichenberg and Mayer, 2006).

Numerous polymer-based sampling techniques have been developed to determine the chemical activity and bioaccessibility of organic contaminants (Bao and Zeng, 2011; 
76 Cui et al., 2013; Cachada et al., 2014). The conventional way to assess the chemical

77 activity of an organic contaminant (i.e., $\mathrm{C}_{\text {free }}$ ) is to use non-depletive equilibrium

78 passive sampling (Reichenberg and Mayer, 2006). The depletion of the PAHs by the

79 polymer needs to be negligible, e.g., $5 \%$ of the total amount, to avoid an artefactual

80 reduction of $\mathrm{C}_{\text {free }}$ before it is measured. To fulfil this condition, previous

81 investigations have proposed the following relationship between the polymer and the

82 sample (Eq. 1) (Mayer et al., 2003; Witt et al., 2013; Lang et al., 2015):

$83 \quad \frac{K_{P S} m_{P S}}{K_{O C} m_{O C}}<5 \%$

(Eq. 1)

84

85 where $\mathrm{m}_{\mathrm{oc}}$ is the mass of the organic carbon $(\mathrm{OC})$ in the sediment or soil subjected to

86 the experiment, $\mathrm{K}_{\mathrm{oc}}$ is the compound-specific OC to water partitioning coefficient of

87 the sediment or soil, $\mathrm{K}_{\mathrm{PS}}$ is the partitioning coefficient between the passive sampler

88 (PS) and the water and $\mathrm{m}_{\mathrm{PS}}$ is the mass of the PS used for the experiment.

89 For sorptive bioaccessibility extractions, the sorbent is intended to deplete the sample

90 (Smedes et al., 2012); this can be expressed as (Eq. 2):

$91 K_{P S} m_{P S}>K_{O C} m_{O C}$

92

93 For non-depletion equilibrium sampling and for full-depletion bioaccessibility

94 extraction, the sorption capacity ratio (SCR) of the polymer sorbent has recently been

95 introduced (Hilber et al., 2017) and can be estimated as:

$96 S C R=\frac{K_{P S} m_{P S}}{K_{O C} m_{O C}}$

97

98 Until now, the SCR has only partially been taken into account. It has not yet been 99 fully implemented in the validation of bioaccessibility quantification method, 
100 particularly with polymeric passive sampling techniques in historically contaminated

101 soils.

102 According to this concept, chemical activity is quantified by placing a non-depletive 103 PS such as polyoxymethylene (POM), low-density polyethylene (LDPE), or 104 polydimethylsiloxane (PDMS) in soils or sediment slurries. Among these, POM 105 possesses the following advantages: it has a smooth surface and is physical robust, it 106 is commercially available and it is inexpensive. In addition, POM results showed a 107 strong correlation to PAH accumulation in earthworms and plants roots (Gomez-Eyles 108 et al., 2011) and has been successfully applied to historically contaminated soils (Arp 109 et al., 2014).

110 Conversely, bioaccessibility is measured by mild extractions (Reid et al., 2000b; 111 Cuypers et al., 2002; Liste and Alexander, 2002) and depletive sampling methods 112 (e.g., Tenax $\left.{ }^{\circledR}\right)$ (Cornelissen et al., 1997; Cornelissen et al., 1998; ten Hulscher et al., 113 2003). Recently, a sorptive bioaccessibility extraction (SBE) method using silicone 114 rods was proposed to quantify bioaccessible PAH concentrations (Gouliarmou and 115 Mayer, 2012; Collins et al., 2013; Zhang et al., 2015). Silicone rods are used here as a sorptive sink (i.e., full depletion) in order to measure bioaccessibility. The silicone rod 117 is ideal for this purpose since it provides a desirable combination of a high 118 partitioning coefficient and a high diffusivity for hydrophobic compounds. This 119 results in a small internal diffusive resistance within the polymer and facilitates 120 continuous absorption of the mobilised PAHs. In addition, silicone rods can be 121 separated quite easily from the suspended matrix at the end of the experiment, in contrast to the well-established Tenax ${ }^{\circledR}$ method. Finally, the SBE method includes

123 the silicone rods as an additional sorptive sink in the solution, which increases the 124 extraction capacity in comparison to other methods (Gouliarmou and Mayer, 2012; 
125 Gouliarmou et al., 2013). Although the SBE method has effectively been used in 126 some studies (Gouliarmou and Mayer, 2012; Collins et al., 2013; Gouliarmou et al., 127 2013; Mayer et al., 2016), it has not been systematically evaluated whether SBE 128 provides a sufficient sorption capacity for a wide variety of soil and sediment 129 samples, taking account of the essential pre-requisite given by Equation 2.

130 The aim of the present study is to test the suitability of the SBE method as a practical 131 tool to characterise PAH bioaccessibility in soil. We selected 35 different sites with 132 historical PAH contamination encompassing 28 soil samples from Switzerland 133 (Bucheli et al., 2004; Desaules et al., 2008; Agarwal and Bucheli, 2011; Gubler et al., 134 2015; FaBo, 2017), which can be considered representative of soils from Central 135 Europe, and seven soil samples from Cuba, to include soils from tropical and 136 Caribbean regions. We investigated how the extractability of PAH by means of SBE 137 in this variety of soils related to total and POM-measured freely dissolved 138 concentrations of the PAH, in dependence of sources of contamination and soil 139 properties. Our intention was first to test the feasibility of the SBE method and the 140 possibility of including it in future risk assessment. The results will help evaluate the 141 potential applicability of the SBE method, including its difficulties and limitations. 142 All results are gathered from historically contaminated soils which are known to have 143 sorption characteristics that are different from "laboratory-spiked" soil, essentially 144 due to "aging" (Alexander, 2000; Cornelissen et al., 2005).

\section{Materials and Methods}

2.1. Chemicals

148 The PAHs we analysed included the following 16 compounds $\left(\mathrm{PAH}_{16}\right)$, as prioritised 149 by the US Environmental Protection Agency (EPA) (NTP, 2005; Andersson and 
150 Achten, 2015): naphthalene (NAP), acenaphthylene (ACY), acenaphthene (ACE),

151 fluorene (FLU), phenanthrene (PHE), anthracene (ANT), fluoranthene (FLT), pyrene 152 (PYR), benzo[a]anthracene (BaA), chrysene (CHR), benzo[b]fluoranthene (BbF), 153 benzo[k]fluoranthene $(\mathrm{BkF})$, benzo[a]pyrene (BaP), indeno[1,2,3-cd]pyrene (IPY), 154 dibenzo[a,h]anthracene (DBA) and benzo[ghi]perylene (BPE). The sum of these is 155 abbreviated as $\sum \mathrm{PAH}_{16}$. The logarithms of their octanol-water $\left(\mathrm{K}_{\mathrm{OW}}\right)$ (Smedes et al., 156 2009), POM-water ( $\mathrm{K}_{\mathrm{D}, \mathrm{POM}}$ ) (Hawthorne et al., 2011) and silicone rod-water 157 partitioning coefficients $\left(\mathrm{K}_{\mathrm{D} \text {,silirod }}\right)$ (Smedes et al., 2009) are summarised in the 158 supplementary information file (SI), Table S1.

159

\subsection{Selection and description of soil samples}

The soil samples $(\mathrm{N}=35)$ included 21 samples (KABO1- KABO21) from the monitoring network (KABO) of the Canton of Zurich, Switzerland (FaBo, 2017), seven samples (NABO1- NABO7) from the Swiss National Monitoring Network

164 (NABO) (Bucheli et al., 2004; Desaules et al., 2008; Agarwal and Bucheli, 2011; Gubler et al., 2015), and seven samples (CUBA1- CUBA7) from Cuba. The latter were collected in collaboration with the Centro Nacional de Sanidad Agropecuaria (CENSA) in San José de las Lajas, Cuba.

168 The main prerequisites for the selection of the soil samples included representing 169 different petrogenic and pyrogenic sources of contamination (SI, Table S2 and Table 170 S3), soil properties such as total organic carbon (TOC) and black carbon (BC) (SI, 171 Table $\mathrm{S} 4)$ and a large range of total soil PAH concentrations $\left(\mathrm{C}_{\mathrm{tot}}\right)$ (SI, Table S5) 172 (Bucheli et al., 2004; Desaules et al., 2008; Agarwal and Bucheli, 2011; Gubler et al., 173 2015; FaBo, 2017). Total organic carbon and BC were quantified using the method 
developed by Agarwal and Bucheli (2011). The $\mathrm{C}_{\mathrm{tot}}$ of the $\sum \mathrm{PAH}_{16}$ varied over four orders of magnitude, from 0.4 to $2137 \mathrm{mg} \mathrm{kg}^{-1}$ (FaBo, 2017).

2.3. Quantification of freely dissolved PAH concentrations $\left(\mathrm{C}_{\text {free }}\right)$ in soil suspensions Polyoxymethylene (POM; $75 \mu \mathrm{m}$ thick. CSHYDE Company, Lake Villa, USA) was used for equilibrium passive sampling to quantify the $\mathrm{C}_{\text {free }}$ of the native PAHs in the soil suspensions. Polyoxymethylene strips were cut into rectangles of $2 \mathrm{~cm} \times 4 \mathrm{~cm}$ (ca. $100 \mathrm{mg}$ ) (Hale et al., 2012). Before the experiment, POM strips were cleaned by sequential solvent extraction, twice in heptane, twice in methanol and finally twice in Milli-Q water (Millipore, Billerica, MS, USA) with the aid of sonication, and stored in Milli-Q water until use.

For each analysis, a POM strip and a soil aliquot (around one gram) were suspended in $40 \mathrm{~mL}$ of Milli-Q water, to which $0.2 \mathrm{~g} \mathrm{~L}^{-1} \mathrm{NaN}_{3}$ had been given to prevent microbial PAH degradation, in a $100 \mathrm{~mL}$ glass bottle (Schott Duran, Mainz, Germany) and closed with a Teflon (PTFE)-lined screw cap. The bottles were shaken for 30 days at $150 \mathrm{rpm}$ on a horizontal orbital shaker (SM 25, Haska AG, Bern, Switzerland) at constant room temperature in the dark. Then the POM strips were removed from the soil suspension, washed carefully with Milli-Q water, cleaned and dried with a lint-free tissue to remove any soil particles and placed in a conical flask (with glass stoppers) with $20 \mathrm{~mL}$ of an acetone/heptane solution (20:80, vol/vol). The extraction solution was spiked with a d-PAH internal standard containing the 16 corresponding perdeuterated PAHs. After two days, the extracts were concentrated in a Syncore Analyst (Büchi Labortechnik AG, Flawil, Switzerland) to $1 \mathrm{~mL}$ and spiked with recovery standard (Indeno[1,2,3-cd]fluoranthene) for gas chromatograph-mass spectrometry (GC-MS) analysis. The PAHs within the extracts were quantified using 
199 the internal standard method and calibration standards with different amounts of

200 analytes $\left(10-2500 \mu \mathrm{g} \mathrm{L}^{-1}\right)$.

201 The values of the POM-water partitioning coefficient ( $\left.\mathrm{K}_{\mathrm{D} \text {,POM }}\right)$ (SI, Table $\mathrm{S} 1$ ) for the 202 individual PAH compounds were taken from Hawthorne et al. (Hawthorne et al., 203 2011). The soil- water partitioning coefficients $\left(K_{D}\right)$ were calculated as the ratio 204 between the $\mathrm{C}_{\text {tot }}$ as previous reported studies (FaBo, 2017) and the $\mathrm{C}_{\text {free }}$ quantified 205 here, which refers to the chemical's concentration in the solution (Schwarzenbach et 206 al., 2005).

\subsection{Sorptive Bioaccessibility Extraction (SBE)}

209 The bioaccessible PAH concentrations of the soil samples were determined as 210 described by Gouliarmou and Mayer (2012) from the PAH mass quantified in the 211 silicone rods $\left(\mathrm{C}_{\text {bioacc }}, \mu \mathrm{g} \mathrm{kg}^{-1}\right.$ soil dry weight $\left.(\mathrm{dw})\right)$. Translucent silicone rods were used as 212 absorptive sinks. These rods were custom made and supplied by Altec (Cornwall, 213 UK), and their partitioning properties for PAHs were recently referenced against a 214 wide range of other silicon materials and one LDPE material (Gilbert et al., 2016) $215\left(\log _{10} \mathrm{~K}_{\mathrm{D}, \text { silirod }}\right.$ values are listed in the SI, Table S1). They had a diameter of $3 \mathrm{~mm} \pm$ $2160.15 \mathrm{~mm}$ and a nominal hardness of $60^{\circ}$ Shore A. To clean them before use, they were 217 first washed with detergent by hand and then by machine to remove talc particles. 218 Thereafter, they were Soxhlet extracted with ethyl acetate for $100 \mathrm{~h}$. The cleaned rods 219 were stored in a sealed bottle with acetone until use. Before starting an experiment, 220 the rods were soaked three times for at least one hour in Milli-Q water to remove any 221 absorbed acetone.

222 Three meters of cleaned rod (mass of the silicone rod, $\mathrm{m}_{\text {silirod }}=24 \mathrm{~g}$ ) were placed in a $223100 \mathrm{~mL}$ glass bottle type Schott Duran (Mainz, Germany) with Teflon (PTFE)-lined 
224 screw caps. Depending on $\mathrm{C}_{\text {tot }}$, one to $10 \mathrm{~g}$ of soil was added, and the bottle was filled

225 with $50 \mathrm{~mL}$ of a hydroxylpropyl-cyclodextrin (HPCD) solution (75 $\mathrm{g}_{\mathrm{HPCD}} \mathrm{L}^{-1}$ Milli-Q-

226 water) and $200 \mathrm{mg} \mathrm{L}^{-1} \mathrm{NaN}_{3}$. The HPCD solution was added to enhance PAH transfer

227 from the soil into the silicone rod (Gouliarmou and Mayer, 2012). The bottles were

228 shaken for seven days at $40 \mathrm{rpm}$ in an overhead shaker at room temperature in the 229 dark. As PAH uptake into silicone rods is fast, these conditions allow for a complete 230 mass transfer of desorbed PAHs into the silicone rod (Gouliarmou and Mayer, 2012).

231 Thereafter, the silicone rods were removed, rinsed with Milli-Q- water, cleaned and 232 dried with a lint-free tissue to remove any remaining soil particles from the surface. 233 PAH extraction from the rods was carried out overnight, by immersing the rods into $234100 \mathrm{~mL}$ acetone, spiked with a d-PAH internal standard solution containing the 16 235 corresponding perdeuterated PAHs. This procedure was repeated with another 100 $236 \mathrm{~mL}$ acetone over a second night. The two acetone extracts were combined and 237 concentrated to $1 \mathrm{~mL}$ in a Syncore Analyst. The extracts were cleaned by means of 238 9:1 (vol/vol) N,N-dimethylformamide-Milli-Q water liquid-liquid partitioning, 239 followed by a column of water-deactivated silica gel to remove any silicone residues. 240 Finally, the $\mathrm{PAH}_{16}$ were analysed by GC-MS. The PAHs within the extracts were 241 quantified using the internal standard method and calibration standards with different 242 amounts of analytes $\left(10-2500 \mu \mathrm{g} \mathrm{L}^{-1}\right)$.

244 2.5. Quality control and assurance

245 Method detection (MDL) and quantification (MQL) limits were determined for each 246 individual PAH by three and ten times the signal over the noise of soil extract 247 chromatograms, respectively, and corresponding quantified concentrations. They were 248 obtained as median values from six soils of different types or with different sources of 
249 contamination. The MDL and MQL of $\mathrm{C}_{\text {free }}$ ranged from 0.002 to $6.12 \mathrm{ng} \mathrm{L}^{-1} \mathrm{PW}$ and

250 from 0.006 to $20.4 \mathrm{ng} \mathrm{L}_{\mathrm{PW}}^{-1}$, respectively (SI, Table S7). The MDL and MQL of $251 \mathrm{C}_{\text {bioacc }}$ ranged from 0.084 to $0.492 \mu \mathrm{g} \mathrm{kg}^{-1}$ soil, and from 0.279 to $1.64 \mu \mathrm{g} \mathrm{kg}^{-1}$ soil, 252 respectively (SI, Table S13).

253 For both chemical methods, analyses were carried out in triplicate with sample 254 replicates processed and analysed in different batches. The $\mathrm{C}_{\text {free }}$ and $\mathrm{C}_{\text {bioacc }}$ of all PAH 255 compounds were well above the corresponding MDLs (Figures S2 and S4, 256 respectively, solid lines). Generally, concentrations were also above the MQL (dashed 257 line) and blank levels (yellow dashed lines). For the interpretation of the results, 258 MDLs were taken as lower limits. Average extraction standard recoveries for the $\mathrm{C}_{\text {free }}$ 259 and $\mathrm{C}_{\text {bioacc }}$ of the 16 deuterated PAHs ranged from 32 to $73 \%$ and from 12 to $77 \%$, 260 respectively (SI, Table S10 and S17). While low absolute recoveries of low molecular 261 weight PAHs (LMW PAHs) were reported earlier, it is possible to compensate 262 successfully for these losses by the use of deuterated analogues (Bucheli et al., 2004). 263 Blanks and control samples were included in duplicate in each batch. The control soil 264 was a well characterised soil sample of the NABO (KB6) and was selected because its $265 \mathrm{C}_{\text {tot }}$ was high enough to be quantified by these chemical methods $\left(\mathrm{C}_{\text {tot }, \text { PAH16 }}=4326\right.$ $266 \mu \mathrm{g} \mathrm{kg}^{-1}$ ). Analytical repeatability (from the same batch) and reproducibility (among 267 batches) from control results were calculated for each PAH compound individually, 268 and ranged from 0.071 to $135.00 \mathrm{ng} \mathrm{L}^{-1}{ }_{\mathrm{PW}}$ and 0.085 to $111.00 \mathrm{ng} \mathrm{L}^{-1}{ }_{\mathrm{PW}}$, respectively, 269 for $\mathrm{C}_{\text {free }}$ (SI, Table S9) and from 0.58 to $342.23 \mu \mathrm{g} \mathrm{kg}^{-1}$ soil and from 0.64 to $291.90 \mu \mathrm{g}$ $270 \mathrm{~kg}^{-1}$ soil, respectively, for $\mathrm{C}_{\text {bioacc }}$ (SI, Table $\mathrm{S} 15$ ). The relative standard deviations 271 (RSDs, standard deviation over mean concentration) of the analytes ranged from 0.21 272 to $24 \%$ for $\mathrm{C}_{\text {free }}$ and from 0.9 to $49 \%$ for $\mathrm{C}_{\text {bioacc. }}$ 
273 While PAHs can adsorb to glassware during POM passive sampling and SBE (Hsieh

274 et al., 2011), this issue was negligible in our experiments due to the drastically higher

275 sorption capacity of the silicone rod and the POM strips in comparison with the glass

276 surface (roughly three and five orders of magnitude, respectively) (SI, Figure S7).

278 2.6. Data evaluation

279 The hypothesis leading to an Analysis of Variance (ANOVA) were (1) soil 280 parameters such as TOC, pollutant properties such as $\mathrm{K}_{\mathrm{OW}}$, and the source of 281 contamination influence the $\mathrm{K}_{\mathrm{D}}$ of the PAH compounds, and (2) the same properties

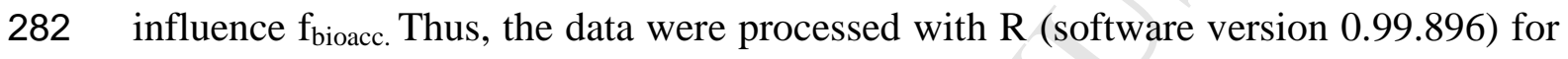
283 an ANOVA. One was run with $\mathrm{K}_{\mathrm{D}}$ as dependent variable and pollutant sources (SI,

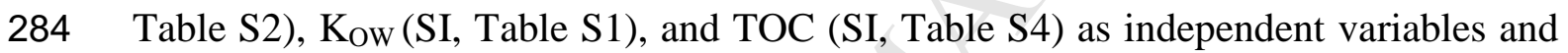
285 one with $f_{\text {bioacc }}$ as dependent and the same independent variables. If p-values were $286 \leq 0.05$ the influence of the parameters on $\mathrm{K}_{\mathrm{D}}$ or $\mathrm{f}_{\text {bioacc }}$ was significant.

\section{Results and Discussion}

290 3.1. Soil specific $\mathrm{K}_{\mathrm{OC}}$ values for the range of PAH contaminated soils

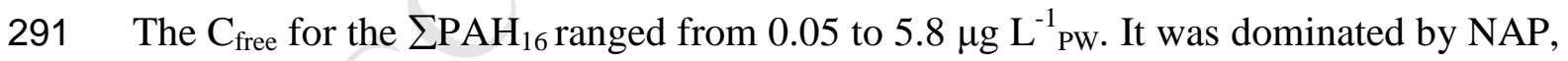
292 PHE and FLT, which contributed more than $60 \%$ to the total (data for individual 293 compounds are presented as SI in Table S6).

294 The compound specific organic carbon to soil-water partitioning coefficients were 295 calculated according to Eq. 4. The $\mathrm{K}_{\mathrm{OC}}$ values of individual PAHs were plotted 296 against the respective values of the octanol-water partitioning coefficient $\left(\mathrm{K}_{\mathrm{OW}}\right)$ in 297 Figure 1. 
$K_{O C}=\frac{C_{t o t} / C_{P W}}{f_{T O C}}=\frac{K_{D}}{f_{T O C}}$
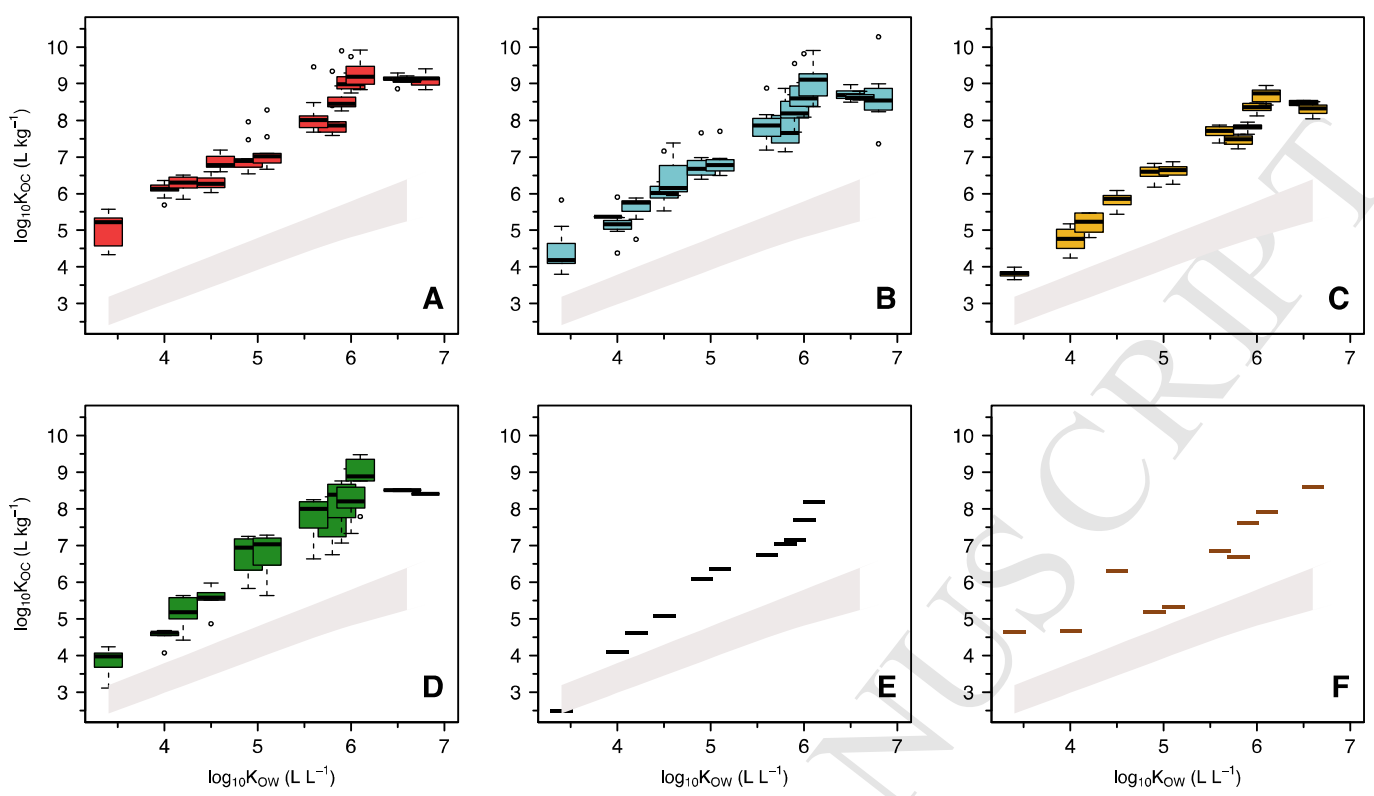

Figure 1: Measurements of the compound specific organic carbon to soil-water partitioning coefficients $\left(\mathrm{K}_{\mathrm{OC}}\right)$ vs. octanol-water partitioning coefficient $\left(\mathrm{K}_{\mathrm{OW}}\right)$ for the 16 US EPA PAHs analysed in the 35 experimental soils of this study. The grey band represents the range of $\mathrm{K}_{\mathrm{OC}}$ values predicted by various $\mathrm{TOC}$ based partitioning models (Karickhoff et al., 1979; Means et al., 1980; Schwarzenbach and Westall, 1981). Results are arranged by source of contamination and land use. A: skeet soils (N=9), B: traffic soils $(\mathrm{N}=12), \mathrm{C}$ : urban garden soils $(\mathrm{N}=6), \mathrm{D}$ : rural soils $(\mathrm{N}=6), \mathrm{E}$ : forest soil $(\mathrm{N}=1)$ and $\mathrm{F}$ : petrogenically contaminated soil $(\mathrm{N}=1)$.

Figure 1 shows that the $\log _{10} \mathrm{~K}_{\mathrm{OC}}$ values ranged from 2.5 for NAP to 10.3 for BPE.

311 The measured $\mathrm{K}_{\mathrm{OC}}$ values were, in all cases, considerably higher than the predictions 312 obtained using empirical models (Karickhoff et al., 1979; Means et al., 1980;

313 Schwarzenbach and Westall, 1981). The deviation between measurements and model 314 prediction may be due to the fact that current models are based on data from 
315 artificially contaminated soils, where the aging time is mostly too short to establish

316 phase distribution equilibrium (Alexander, 2000; Brand et al., 2013) and that the

317 amount of sorbents, either amorphous or condensed, was limited (Cornelissen et al.,

318 2005). Furthermore, these models are based on experiments in which high

319 concentrations of PAH were applied as spikes. In contrast, all measurements in the

320 present study were based on native PAHs in historically contaminated soils. This

321 implies an aging effect and also means that the concentrations were generally in a

322 lower range than those used in the models. Finally, for calculating the experimental

$323 \mathrm{~K}_{\mathrm{OC}}$ values presented here, we used the $\mathrm{K}_{\mathrm{D} \text {,POM }}$ values published by Hawthorne et al.

324 (Hawthorne et al., 2011), which were recommended by Arp et al. (Arp et al., 2015).

325 These values, however, are in the upper range of the published values and translated 326 into relatively high $\mathrm{K}_{\mathrm{OC}}$ values.

327 The first hypothesis of the chapter 2.6 was tested and ANOVA results showed a 328 significant influence of source and $\mathrm{K}_{\mathrm{OW}}$ on the $\mathrm{K}_{\mathrm{D}}(\mathrm{p}<2 \mathrm{E}-16)$ of the PAH compounds 329 but not so the TOC. This is in the line with previous studies where, in case of severe 330 pollution, the nature of the pollutant source plays a more important role for PAH 331 partitioning and bioavailability than native soil parameters (Baumard et al., 1998; 332 Kołtowski et al., 2016; Xia et al., 2016). This was probably the case for most of the 333 (contaminated) soils investigated here, since no clear influence of soil TOC and BC 334 content (SI, Table S4) on $\mathrm{C}_{\text {free }}$ and $\mathrm{K}_{\mathrm{OC}}$ was discernible. In our experiment, the skeet 335 soils that were contaminated by coal-tar pitch exhibited the highest $\log _{10} \mathrm{~K}_{\mathrm{OC}}$ values, 336 ranging from 5.2 for NAP to 9.4 for BaP (Figure 1A). These are in concordance with 337 the values found by Xia et al. (Xia et al., 2016). This is plausible because weathered 338 coal-tar components of pitch contain BC, in the form of soot, coke and cenospheres. 339 In the production process, these $\mathrm{BC}$ materials are incorporated in firing the clay-tar 
340 composite. An increase in sorption capacity of soil and sediments contaminated by

341 weathered coal-tar pitch has already been reported (Khalil et al., 2006; Smith et al.,

342 2011; Xia et al., 2016). The soils with pyrogenic contamination (traffic road and

343 urban garden) showed intermediate $\mathrm{K}_{\mathrm{OC}}$ values (Figures $1 \mathrm{~B}$ and $1 \mathrm{C}$ ). The soils that

344 had been exposed to traffic emissions (Figure 1B), and thus mainly to soot-like

345 material, showed higher $\mathrm{K}_{\mathrm{OC}}$ values than those of urban garden soils (Figure 1C),

346 where the contaminants presumably originated from the combustion of charcoal or

347 coal material. Such source-dependent differences, with the highest $\mathrm{K}_{\mathrm{OC}}$ values for

348 traffic soot, and lower ones for charcoal are in agreement with earlier findings (Jonker

349 and Koelmans, 2002). The lowest $\mathrm{K}_{\mathrm{OC}}$ values were observed in the soil contaminated

350 from a petrogenic source (Figure 1F). This is because of the rubbery-like carbon

351 material. PAHs entering soils with petrogenic materials are known to be more

352 available than PAHs from pyrogenic inputs (Koelmans et al., 2006). The rural soils

353 showed a particularly high variability in $\mathrm{K}_{\mathrm{OC}}$ values. These soils were exposed to

354 various diffuse sources, including emissions from industry, traffic and households.

355 The only soil sample taken in a forest had a rather low $\mathrm{K}_{\mathrm{OC}}$ value (Figure 1E).

356 In summary, these results are in line with earlier findings of lower $\mathrm{K}_{\mathrm{OC}}$ values and

357 corresponding higher $\mathrm{C}_{\text {free }}$ values of PAHs in soils the PAH contamination of which is

358 associated with amorphous organic matter, rather than with condensed carbonaceous

359 material (i.e., pyrogenic PAHs) (Thorsen et al., 2004; Xia et al., 2016). In addition,

360 the high $\mathrm{K}_{\mathrm{OC}}$ values of pyrogenic PAHs are attributed to their co-emission with

361 corresponding geosorbents, such as soot. Our $\mathrm{K}_{\mathrm{OC}}$ values were, on average, slightly

362 higher than those obtained by the POM method in other historically contaminated

363 soils or sediments (Jonker and Smedes, 2000; Arp et al., 2014) (SI, Figure S3). This is 
364 mainly due to the large contribution in the data set $(\mathrm{N}=9)$ of the high $\mathrm{K}_{\mathrm{OC}}$ results

365 obtained from the skeet soils.

367 3.2. Sorptive bioaccessibility extraction (SBE) of PAHs from soils

368 3.2.1. Influence of sorption capacities ratio (SCR) on bioaccessibility

369 Irrespective of the SCR, the $\mathrm{C}_{\text {bioacc }}$ obtained by SBE ranged for individual PAHs from 3700.005 for IPY to $17280 \mu \mathrm{g} \mathrm{kg}^{-1}{ }_{\mathrm{dw}}$ for FLT (median= $57.1 \mu \mathrm{g} \mathrm{kg}^{-1}{ }_{\mathrm{dw}}$ SI, Figure S4 and

371 Table S12). Their corresponding fractions ( $f_{\text {bioacc }}$ ) ranged from $0.012 \%$ to $100 \%$, or 372 numerically even higher in a few individual cases (see below), which were calculated 373 by $\mathrm{C}_{\text {bioacc }}$ over $\mathrm{C}_{\text {tot }}$. While $\mathrm{f}_{\text {bioacc }}$ may be the more relevant parameter in terms of 374 environmental chemistry point of view of PAH phase distribution processes, 375 ecotoxicologists, regulators and decision makers may often be more interested in the 376 actual exposure level, as expressed by $\mathrm{C}_{\text {bioacc. }}$.

377 As discussed above, the SBE method can be used as a depletive method to quantify 378 bioaccessibility if SCR (Eq. 3) is larger than one, which means that the product of $379 \mathrm{~K}_{\mathrm{D} \text {,silirod }}$ and $\mathrm{m}_{\text {silirod }}$ is greater than the respective product of the soil sample. Figure 2 380 depicts $\mathrm{f}_{\text {bioacc }}$ vs $\log _{10} \mathrm{SCR}$, as determined for individual PAHs in the 35 different soils. 


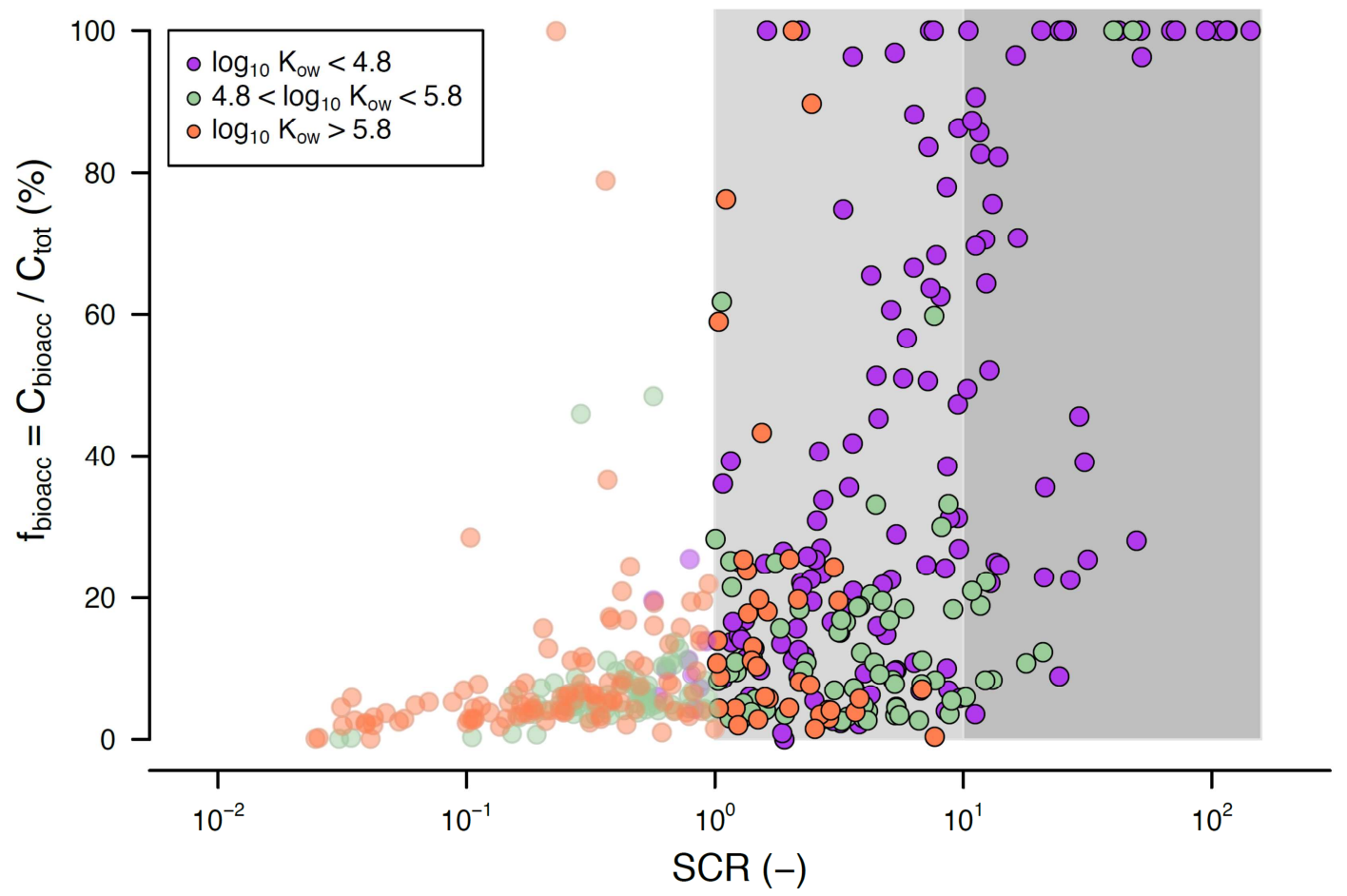

Figure 2: Bioaccessible fractions ( $f_{\text {bioacc }}$ ) of 16 individual US EPA PAHs in the 35 experimental soils vs. their corresponding sorption capacity ratio (SCR; note logarithmic scale). Points within the two shaded areas represent data obtained under depletive conditions ( $\mathrm{SCR}>1$; for details, see text). Points inside the white area represent data that were gathered under insufficient depletion conditions $(\mathrm{SCR}<1)$. Data were grouped by their octanol-water $\left(\mathrm{K}_{\mathrm{OW}}\right)$ partitioning coefficients. The fractions $>100 \%(\mathrm{~N}=5 \%)$ were set to $100 \%$.

391 Figure 2 shows that more than half of the data (57\%) were gathered under depletive conditions (SCR > 1). Only $12 \%$ of the data were obtained at SCR > 10, though, 393 where it can be assured that the silicone rod fully acted as an infinitive sink. 394 Consequently, the $\mathrm{f}_{\text {bioacc }}$ values obtained in these cases can be considered as robust. 395 For those soils or analytes, where the $\mathrm{f}_{\text {bioacc }}$ results were obtained at $1<\mathrm{SCR}<10$, the 396 SBE method may not have provided sufficient sink capacity and $\mathrm{f}_{\text {bioacc }}$ may therefore 
397 have been slightly underestimated. In the remaining cases, the depletion criterion was

398 not fulfilled, and consequently, $\mathrm{f}_{\text {bioacc }}$ was even lower.

399 In general, $\mathrm{C}_{\text {bioacc }}$ and $\mathrm{f}_{\text {bioacc }}$ were successfully quantified for samples with relatively

400 high PAH concentrations and when $\mathrm{K}_{\mathrm{D}}$ values did not exceed $10^{6} \mathrm{~L} \mathrm{~kg}^{-1}$ (SI, Figure

401 S5). This combination of high PAH content and low sorption characterises the highest

402 exposure and risk scenarios, where bioaccessibility measurements are most urgently 403 needed. In contrast, it was more difficult to obtain valid bioaccessibility 404 measurements for combinations of low PAH content and high $\mathrm{K}_{\mathrm{D}}$ values, simply 405 because it was difficult to obtain a sufficiently high SCR ratio. The earlier reported 406 challenge for bioaccessibility measurements of PAHs due to capacity constraints is 407 thus not limited to pure carbonaceous geosorbents such as soot or biochar, but also 408 applies to many historically polluted soils. A large part of those results obtained with $409 \mathrm{SCR}<1$ exhibited $\mathrm{K}_{\mathrm{D}}$ values higher than $10^{6} \mathrm{~L} \mathrm{~kg}^{-1}$ (SI, Figure S5). Compounds with 410 such elevated $K_{D}$ are characterised by a low mobility; in this case, the $K_{D}$ is the ruling 411 factor that renders bioaccessibility difficult to quantify.

412 The sorptive capacity of the applied SBE method is much higher than cyclodextrin 413 extractions, which would provide insufficient sorptive capacity for a much larger 414 fraction of PAH and soil combinations. While the contaminant trap (Mayer et al., 415 2016) can provide much higher sorptive capacity, it is unfortunately not suited to 416 directly measure bioaccessible fractions, and thus it remains a real challenge to 417 measure bioaccessibility for high $\mathrm{K}_{\mathrm{D}}$ situations, simply because it is difficult to 418 provide a sufficient SCR. In principle we could improve the SCR of the system by 419 increasing the mass of the silicone rod. Mayer et al. (2016) (Mayer et al., 2016)tested 420 this option, increasing the mass ratio between sink and sample from 240 up to 9600 $421 \mathrm{~g}_{\text {sink }} \mathrm{g}^{-1}$ sample. Although these conditions provided a sufficient sink capacity, they were 
422 not feasible in practise (30 $\mathrm{m}$ of silicone rods), and prone to artefacts due to the use of

423 a possibly non-representative small amount of sample $(0.025 \mathrm{~g})$. In general, we stress

424 that depletive conditions are not only determined by the favourable mass ratio of PS

425 to sample (ideally $\mathrm{m}_{\mathrm{PS}} / \mathrm{m}_{\mathrm{s}} \rightarrow \infty$, where $\mathrm{m}_{\mathrm{s}}$ is the mass of the solid (Smedes et al.,

426 2012)), but also by the $K_{D}$ of historically contaminated soils or sediments. Therefore,

427 it must be quantified and taken into account during the adaptation and validation of

428 the method for any given set of samples.

429 In some cases, and particularly for LMW PAHs, $\mathrm{f}_{\text {bioacc }}$ was as high as $100 \%$, or even

430 above (Figure 2). One reason for this artefact might be that the extraction conditions

431 to determine $\mathrm{C}_{\text {tot }}$ were not always exhaustive in the first place. Another reason might

432 be that extended wetting during SBE may have removed soluble or hydrophilic soil 433 constituents (Hale et al., 2012), which possibly masked PAHs during $\mathrm{C}_{\text {tot }}$ 434 determination in absence of a suitable solvent mediator.

436 3.2.2. Bioaccessibility estimates obtained under depletive conditions

437 Under depletive conditions ( $\mathrm{SCR}>1$ ), $\mathrm{C}_{\text {bioacc }}$ of individual PAHs ranged from 0.50 to

$43817280 \mu \mathrm{g} \mathrm{kg}_{\mathrm{dw}}^{-1}\left(\right.$ median $\left.=37.43 \mu \mathrm{g} \mathrm{kg}_{\mathrm{dw}}^{-1}\right)$ and are presented in Figure 3 against their 439 corresponding $\mathrm{C}_{\mathrm{tot}}$.

440 In the following, we restrict the discussion of bioaccessibility data to those obtained 441 under depletive criteria sink conditions. The other data are included in the SI Figure 442 S6 (semi-transparent circles), but not interpreted any further.

443 In the second hypothesis (chapter 2.6) test, the ANOVA revealed again that the source 444 of contamination and the $\mathrm{K}_{\mathrm{OW}}$ values significantly influenced $\mathrm{f}_{\text {bioacc }}$ ( $\left.\mathrm{p}<9.5 \mathrm{E}-14\right)$. 445 Soils contaminated with skeet materials had the lowest $\mathrm{f}_{\text {bioacc }}$ (on average, 15\%; 446 Figure $3 \mathrm{~A}$ ), which corresponds to their highest $\mathrm{K}_{\mathrm{OC}}$ values. Intermediate $\mathrm{f}_{\text {bioacc }}$ of $28 \%$ 
447 and $41 \%$, respectively, were obtained from those soils that received PAHs from other

448 pyrogenic sources such as traffic road-side and urban garden soils (Figures 3B and

$4493 \mathrm{C}$ ). Higher $\mathrm{f}_{\text {bioacc }}$ were observed in soils from rural areas (on average, 63\%) and 450 forest (78\%) (Figures 3D and 3E). Rural soils receive LMW PAHs (i.e., those 451 quantified here) primarily via atmospheric transport in the gas phase from long-range 452 transport sources. Such speciation facilitates phase transfer processes, specifically 453 desorption forced by the SBE method, because it is not limited by, for example, 454 physical entrapment in or retarded diffusion from co-emitted particles. The highest $455 \mathrm{f}_{\text {bioacc }}$ (on average, 73\%) was observed for PAHs originating from the petrogenic 456 source (Figure $3 \mathrm{~F}$ ). Similar to the $\mathrm{C}_{\text {free }}$ results (see above), this can be explained with 457 the rubbery-like carbon material in this sample.
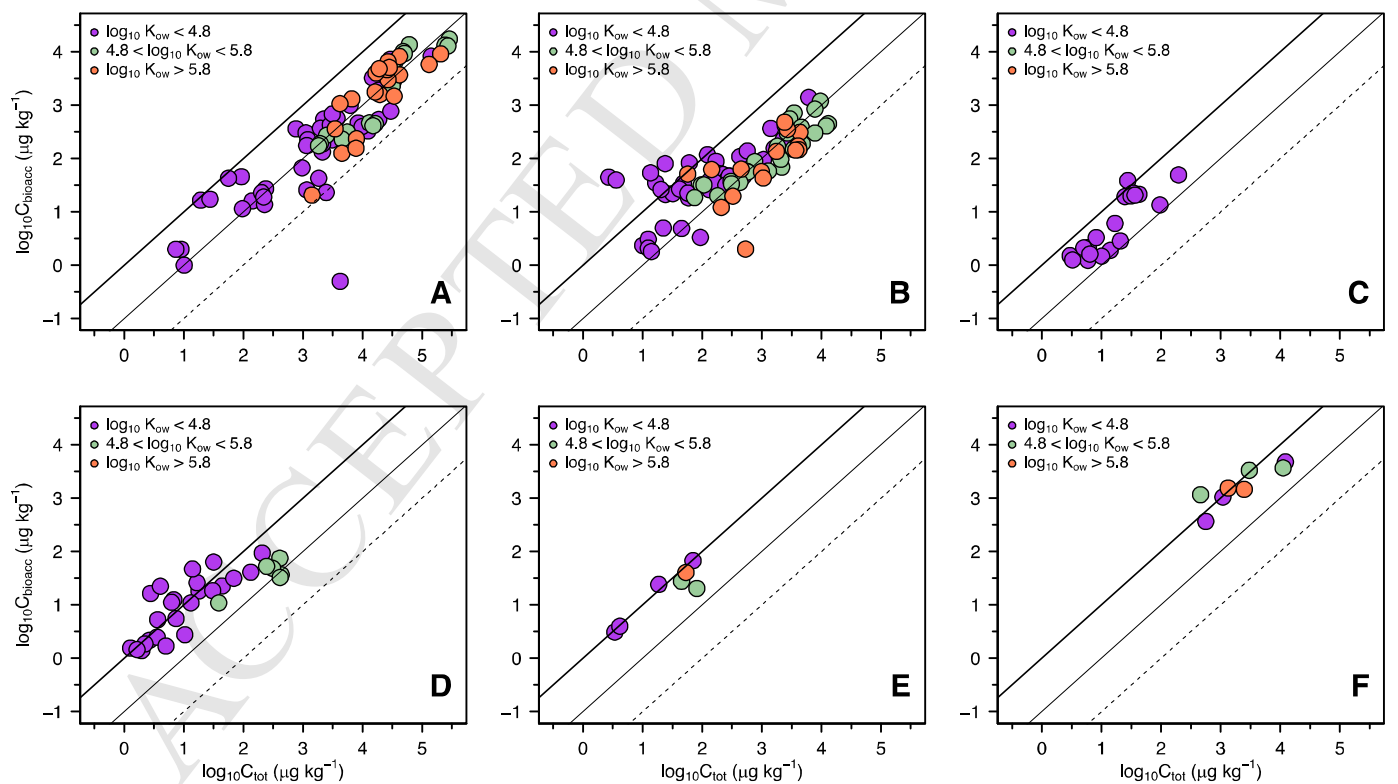

459 Figure 3: Bioaccessible $\left(\mathrm{C}_{\text {bioacc }}\right)$ vs. total concentrations $\left(\mathrm{C}_{\text {tot }}\right)$ for the 16 US EPA

PAHs in the 35 experimental soils. Results are arranged by source of contamination or 
461 specific soil use types. A: skeet soils $(\mathrm{N}=9), \mathrm{B}$ : traffic soils $(\mathrm{N}=12), \mathrm{C}$ : urban garden

462 soils $(\mathrm{N}=6)$, D: rural soils $(\mathrm{N}=6), \mathrm{E}$ : forest soil $(\mathrm{N}=1)$ and $\mathrm{F}$ : petrogenically 463 contaminated soil $(\mathrm{N}=1)$. Data were obtained under (quasi-) depletive sink conditions 464 (SCR > 1; for details, see text). Data were grouped by their octanol-water $\left(\mathrm{K}_{\mathrm{OW}}\right)$ 465 partitioning coefficients. The three black lines represent 1:1 (thick solid lines), 1:10 466 (thin solid lines) and 1:100 (dashed lines) relations, i.e., bioaccessible fractions ( $\left.\mathrm{f}_{\text {bioacc }}\right)$ 467 of $100 \%, 10 \%$ and $1 \%$, respectively.

469 Several studies with contaminated soils and sediments that used SBE or Tenax ${ }^{\circledR}$ under 470 infinitive sink conditions showed that bioaccessibiliy was higher than with only 471 cyclodextrin solution (Gouliarmou et al., 2013; Li et al., 2015; Hong et al., 2016; 472 Ruby et al., 2016). In other studies, the addition of either silicone rods or Tenax ${ }^{\circledR}$ were 473 both found to increase the extraction of PAH from contaminated soil by factors of 474 1.3- 3.1 and 4.4, respectively, compared to the same experiment without the sink 475 material (Collins et al., 2013; Li et al., 2015). Results similar to those of our study 476 were obtained in the only other study using the SBE method with silicone rod in a soil 477 where atmospheric deposition of soot was the main source of PAH contamination 478 (Gouliarmou et al., 2013). There, $\mathrm{f}_{\text {bioacc }}$ results from a kindergarten soil ranged from 6 479 to $50 \%$ for the $\Sigma \mathrm{PAH}_{16}$. A case of high bioaccessibility of PAHs in petrogenic480 contaminated sediments was recently investigated using the Tenax ${ }^{\circledR}$ method (Hong et 481 al., 2016); results were in line with those presented here.

\subsection{Added value of bioaccessibility parameters for risk assessment}

484 With regard to risk assessment and legislation, the presented data suggests that 485 analysis of bioaccessibility by chemical proxies such as the SBE method may not 
486 provide a better basis than $\mathrm{C}_{\text {tot. }}$. In case of low $\mathrm{C}_{\text {tot }}$ (i.e., uncontaminated soils), freely 487 dissolved concentrations and bioaccessibility will never be an issue, even when a 488 large fraction of the total is bioaccessible (which is still a matter of interest from a 489 mechanistic and environmental chemistry point of view, though). In case of high $\mathrm{C}_{\text {tot }}$ 490 (i.e. contaminated soils), bioaccessible concentrations, in most cases, will also be 491 rather high, even when the fraction of bioaccessible PAH is low; therefore, such sites 492 will usually require exposure reduction measures anyway. More meaningful applications of proxies for the assessment of soil PAH bioavailability include the evaluation of in situ remediation measures such as sorbent amendment to reduce PAH exposure and mobility in contaminated soils or sediments, or the substitution of living organisms in exposure experiments.

\section{Conclusions and Outlook}

499 To the best of our knowledge, this is the first paper that used the SBE method to 500 investigate a large number of historically contaminated soils for bioaccessibility of 501 PAHs. In general, the method proved feasible for soil samples with relatively high 502 PAH concentrations and when $K_{D}$ values did not exceed $10^{6} \mathrm{~L} \mathrm{~kg}^{-1}$. In contrast, the 503 method did not always provide sufficient sink capacity when a low PAH content 504 demanded a larger sample mass and $\mathrm{K}_{\mathrm{D}}$ values exceeded $10^{6} \mathrm{~L} \mathrm{~kg}^{-1}$. Therefore, quality 505 assurance and control parameters such as SCR should routinely be determined to 506 critically evaluate the gathered data and avoid misinterpretation. When the SBE is 507 properly applied, these results showed that they mirrored the influence of pollution 508 source or soil type. 
511 This work is part of the project "Establishing a soil monitoring network to assess the

512 environmental exposure to PAHs and PCBs in the province of Mayabeque, Cuba 513 (Soil-Q)", within the Swiss Programme for Research on Global Issues for

514 Development (r4d programme). We thank the Swiss Agency for Development and

515 Cooperation (SDC) and the Swiss National Science Foundation (SNSF) for financial

516 support. The authors would like to thank the monitoring network (KABO) of the

517 Canton of Zurich, Switzerland and the Swiss National Monitoring Network (NABO)

518 for providing the soil samples. This work is partially based on data and samples

519 provided by the Soil Protection Agency (Fachstelle Bodenschutz) of the Canton of 520 Zurich, Switzerland, under contract no. 28093. Finally, the authors thank Regula

521 Wolz Gysi for her English correction support.

522 


\section{References}

524 Agarwal, T., Bucheli, T.D., 2011. Adaptation, validation and application of the chemo-

525 thermal oxidation method to quantify black carbon in soils. Environ. Pollut. 159, 532-538.

526 Alexander, M., 2000. Aging, Bioavailability, and Overestimation of Risk from Environmental

527 Pollutants. Environ. Sci. Technol. 34, 4259-4265.

528 Andersson, J.T., Achten, C., 2015. Time to Say Goodbye to the 16 EPA PAHs? Toward an

529 Up-to-Date Use of PACs for Environmental Purposes. Polycycl. Aromat. Compd. 35, 330530354.

531 Arp, H.P.H., Hale, S.E., Elmquist Kruså, M., Cornelissen, G., Grabanski, C.B., Miller, D.J., 532 Hawthorne, S.B., 2015. Review of polyoxymethylene passive sampling methods for 533 quantifying freely dissolved porewater concentrations of hydrophobic organic contaminants. 534 Environ. Toxicol. Chem. 34, 710-720.

535 Arp, H.P.H., Lundstedt, S., Josefsson, S., Cornelissen, G., Enell, A., Allard, A.-S., Kleja, 536 D.B., 2014. Native Oxy-PAHs, N-PACs, and PAHs in Historically Contaminated Soils from 537 Sweden, Belgium, and France: Their Soil-Porewater Partitioning Behavior, Bioaccumulation 538 in Enchytraeus crypticus, and Bioavailability. Environ. Sci. Technol. 48, 11187-11195.

539 Bao, L.-J., Zeng, E.Y., 2011. Passive sampling techniques for sensing freely dissolved 540 hydrophobic organic chemicals in sediment porewater. Trends Analyt. Chem. 30, 1422-1428.

541 Baumard, P., Budzinski, H., Michon, Q., Garrigues, P., Burgeot, T., Bellocq, J., 1998. Origin 542 and Bioavailability of PAHs in the Mediterranean Sea from Mussel and Sediment Records. 543 Estuar. Coast. Shelf Sci. 47, 77-90.

544 Brand, E., Lijzen, J., Peijnenburg, W., Swartjes, F., 2013. Possibilities of implementation of 545 bioavailability methods for organic contaminants in the Dutch Soil Quality Assessment 546 Framework. J. Hazard. Mater. 261, 833-839.

547 Bucheli, T.D., Blum, F., Desaules, A., Gustafsson, Ö., 2004. Polycyclic aromatic 548 hydrocarbons, black carbon, and molecular markers in soils of Switzerland. Chemosphere 56, 549 1061-1076.

550 Cachada, A., Pereira, R., da Silva, E.F., Duarte, A.C., 2014. The prediction of PAHs 551 bioavailability in soils using chemical methods: State of the art and future challenges. Sci. 552 Total Environ. 472, 463-480.

553 Collins, C.D., Mosquera-Vazquez, M., Gomez-Eyles, J.L., Mayer, P., Gouliarmou, V., Blum, 554 F., 2013. Is there sufficient 'sink' in current bioaccessibility determinations of organic 555 pollutants in soils? Environ. Pollut. 181, 128-132.

556 Swiss Confederation, 2016. Ordinance Relating to the Impacts on Soils. SR 814.12 of July 557 1st, 1998, as by April 12, 2016. https://www.admin.ch/opc/de/classified558 compilation/19981783/201604120000/814.12.pdf. Accessed August 31.2017. 
559 Cornelissen, G., Gustafsson, Ö., Bucheli, T.D., Jonker, M.T.O., Koelmans, A.A., van Noort,

560 P.C.M., 2005. Extensive Sorption of Organic Compounds to Black Carbon, Coal, and

561 Kerogen in Sediments and Soils: Mechanisms and Consequences for Distribution,

562 Bioaccumulation, and Biodegradation. Environ. Sci. Technol. 39, 6881-6895.

563 Cornelissen, G., Rigterink, H., Ferdinandy, M.M.A., van Noort, P.C.M., 1998. Rapidly

564 Desorbing Fractions of PAHs in Contaminated Sediments as a Predictor of the Extent of 565 Bioremediation. Environ. Sci. Technol. 32, 966-970.

566 Cornelissen, G., van Noort, P.C.M., Govers, H.A.J., 1997. Desorption kinetics of 567 chlorobenzenes, polycyclic aromatic hydrocarbons, and polychlorinated biphenyls: Sediment 568 extraction with Tenax ${ }^{\circledR}$ and effects of contact time and solute hydrophobicity. Environ.

569 Toxicol. Chem. 16, 1351-1357.

570 Cui, X., Mayer, P., Gan, J., 2013. Methods to assess bioavailability of hydrophobic organic 571 contaminants: Principles, operations, and limitations. Environ. Pollut. 172, 223-234.

572 Cuypers, C., Pancras, T., Grotenhuis, T., Rulkens, W., 2002. The estimation of PAH 573 bioavailability in contaminated sediments using hydroxypropyl- $\beta$-cyclodextrin and Triton X574100 extraction techniques. Chemosphere 46, 1235-1245.

575 Desaules, A., Ammann, S., Blum, F., Brandli, R.C., Bucheli, T.D., Keller, A., 2008. PAH and 576 PCB in soils of Switzerland-status and critical review. J. Environ. Monitor. 10, 1265-1277.

577 FaBo, 2017. Fachstelle Bodenschutz . Unpublished data.

578 https://aln.zh.ch/internet/baudirektion/aln/de/fabo.html. Accessed September 13.2017.

579 Gilbert, D., Witt, G., Smedes, F., Mayer, P., 2016. Polymers as Reference Partitioning Phase:

580 Polymer Calibration for an Analytically Operational Approach To Quantify Multimedia 581 Phase Partitioning. Anal. Chem. 88, 5818-5826.

582 Gomez-Eyles, J.L., Jonker, M.T.O., Hodson, M.E., Collins, C.D., 2011. Passive Samplers

583 Provide a Better Prediction of PAH Bioaccumulation in Earthworms and Plant Roots than

584 Exhaustive, Mild Solvent, and Cyclodextrin Extractions. Environ. Sci. Technol. 46, 962-969.

585 Gouliarmou, V., Collins, C.D., Christiansen, E., Mayer, P., 2013. Sorptive Physiologically

586 Based Extraction of Contaminated Solid Matrices: Incorporating Silicone Rod As Absorption

587 Sink for Hydrophobic Organic Contaminants. Environ. Sci. Technol. 47, 941-948.

588 Gouliarmou, V., Mayer, P., 2012. Sorptive Bioaccessibility Extraction (SBE) of Soils:

589 Combining a Mobilization Medium with an Absorption Sink. Environ. Sci. Technol. 46, $590 \quad 10682-10689$.

591 Gubler, A., Wachter, D., Blum, F., Bucheli, T.D., 2015. Remarkably constant PAH 592 concentrations in Swiss soils over the last 30 years. Environ. Sci. Process. Impact 17, 18165931828.

594 Hale, S.E., Lehmann, J., Rutherford, D., Zimmerman, A.R., Bachmann, R.T., Shitumbanuma, 595 V., O’Toole, A., Sundqvist, K.L., Arp, H.P.H., Cornelissen, G., 2012. Quantifying the Total 
596 and Bioavailable Polycyclic Aromatic Hydrocarbons and Dioxins in Biochars. Environ. Sci.

597 Technol. 46, 2830-2838.

598 Hawthorne, S.B., Jonker, M.T.O., van der Heijden, S.A., Grabanski, C.B., Azzolina, N.A.,

599 Miller, D.J., 2011. Measuring Picogram per Liter Concentrations of Freely Dissolved Parent 600 and Alkyl PAHs (PAH-34), Using Passive Sampling with Polyoxymethylene. Anal. Chem. $60183,6754-6761$.

602 Hilber, I., Bastos, A.C., Loureiro, S., Soja, G., Marsz, A., Cornelissen, G., Bucheli, T.D., 603 2017. The different faces of biochar: contamination risk versus remediation tool. J. Environ. 604 Eng. Landsc., 1-19.

605 Hong, S., Yim, U.H., Ha, S.Y., Shim, W.J., Jeon, S., Lee, S., Kim, C., Choi, K., Jung, J., 606 Giesy, J.P., Khim, J.S., 2016. Bioaccessibility of AhR-active PAHs in sediments 607 contaminated by the Hebei Spirit oil spill: Application of Tenax extraction in effect-directed 608 analysis. Chemosphere 144, 706-712.

609 Hsieh, M.-K., Fu, C.-T., Wu, S.-c., 2011. Simultaneous Estimation of Glass-Water 610 Distribution and PDMS-Water Partition Coefficients of Hydrophobic Organic Compounds 611 Using Simple Batch Method. Environ. Sci. Technol. 45, 7785-7791.

612 Jonker, M.T.O., Koelmans, A.A., 2002. Sorption of Polycyclic Aromatic Hydrocarbons and 613 Polychlorinated Biphenyls to Soot and Soot-like Materials in the Aqueous Environment: 614 Mechanistic Considerations. Environ. Sci. Technol. 36, 3725-3734.

615 Jonker, M.T.O., Smedes, F., 2000. Preferential Sorption of Planar Contaminants in Sediments 616 from Lake Ketelmeer, The Netherlands. Environ. Sci. Technol. 34, 1620-1626.

617 Karickhoff, S.W., Brown, D.S., Scott, T.A., 1979. Sorption of hydrophobic pollutants on 618 natural sediments. Water Res. 13, 241-248.

619 Khalil, M.F., Ghosh, U., Kreitinger, J.P., 2006. Role of Weathered Coal Tar Pitch in the 620 Partitioning of Polycyclic Aromatic Hydrocarbons in Manufactured Gas Plant Site Sediments. 621 Environ. Sci. Technol. 40, 5681-5687.

622 Koelmans, A.A., Jonker, M.T.O., Cornelissen, G., Bucheli, T.D., Van Noort, P.C.M., 623 Gustafsson, Ö., 2006. Black carbon: The reverse of its dark side. Chemosphere 63, 365-377.

624 Kołtowski, M., Hilber, I., Bucheli, T.D., Oleszczuk, P., 2016. Effect of activated carbon and 625 biochars on the bioavailability of polycyclic aromatic hydrocarbons in different industrially 626 contaminated soils. Environ. Sci. Pollut. R 23, 11058-11068.

627 Lang, S.-C., Hursthouse, A., Mayer, P., Kötke, D., Hand, I., Schulz-Bull, D., Witt, G., 2015. 628 Equilibrium passive sampling as a tool to study polycyclic aromatic hydrocarbons in Baltic 629 Sea sediment pore-water systems. Marine Poll. Bull. 101, 296-303.

630 Li, C., Cui, X.Y., Fan, Y.Y., Teng, Y., Nan, Z.R., Ma, L.Q., 2015. Tenax as sorption sink for 631 in vitro bioaccessibility measurement of polycyclic aromatic hydrocarbons in soils. Environ. 632 Pollut. 196, 47-52. 
633 Liste, H.-H., Alexander, M., 2002. Butanol extraction to predict bioavailability of PAHs in 634 soil. Chemosphere 46, 1011-1017.

635 Mayer, P., Hilber, I., Gouliarmou, V., Hale, S.E., Cornelissen, G., Bucheli, T.D., 2016. How

636 to Determine the Environmental Exposure of PAHs Originating from Biochar. Environ. Sci.

637 Technol. 50, 1941-1948.

638 Mayer, P., Tolls, J., Hermens, J.L.M., Mackay, D., 2003. Peer Reviewed: Equilibrium 639 Sampling Devices. Environ. Sci. Technol. 37, 184A-191A.

640 Means, J.C., Wood, S.G., Hassett, J.J., Banwart, W.L., 1980. Sorption of polynuclear 641 aromatic hydrocarbons by sediments and soils. Environ. Sci. Technol. 14, 1524-1528.

642 NTP, 2005. Report on Carcinogens, eleventh ed. National Toxicology Program (NTP). Public

643 Health Service, US Department of Health and Human Services, Washington, DC.

644 Ortega-Calvo, J.-J., Harmsen, J., Parsons, J.R., Semple, K.T., Aitken, M.D., Ajao, C.,

645 Eadsforth, C., Galay-Burgos, M., Naidu, R., Oliver, R., Peijnenburg, W.J.G.M., Römbke, J.,

646 Streck, G., Versonnen, B., 2015. From Bioavailability Science to Regulation of Organic

647 Chemicals. Environ. Sci. Technol. 49, 10255-10264.

648 Regulation (EC) No 1907/2006 of the European Parliament and of the Council, 2006 649 Registration, Evaluation, Authorisation and Restriction of Chemicals (REACH), establishing 650 a European Chemicals Agency, amending Directive 1999/45/EC and repealing Council 651 Regulation (EEC) No 793/93 and Comission Regulation (EC) No 1488/94 as well as Council 652 Directive 76/769/EEC and Comission Directives 91/155/EEC, 93/67/EEC, 93/105/EC and 653 2000/21/EC. Official Journal European Union L136, 1-849.

654 Reichenberg, F., Mayer, P., 2006. Two complementary sides of bioavailability: Accessibility 655 and chemical activity of organic contaminants in sediments and soils. Environ. Toxicol. 656 Chem. 25, 1239-1245.

657 Reid, B.J., Jones, K.C., Semple, K.T., 2000a. Bioavailability of persistent organic pollutants 658 in soils and sediments - a perspective on mechanisms, consequences and assessment. 659 Environ. Pollut. 108, 103-112.

660 Reid, B.J., Stokes, J.D., Jones, K.C., Semple, K.T., 2000b. Nonexhaustive Cyclodextrin661 Based Extraction Technique for the Evaluation of PAH Bioavailability. Environ. Sci. 662 Technol. 34, 3174-3179.

663 Ruby, M.V., Lowney, Y.W., Bunge, A.L., Roberts, S.M., Gomez-Eyles, J.L., Ghosh, U., 664 Kissel, J.C., Tomlinson, P., Menzie, C., 2016. Oral Bioavailability, Bioaccessibility, and 665 Dermal Absorption of PAHs from Soil-State of the Science. Environ. Sci. Technol. 50, $666 \quad 2151-2164$.

667 Schwarzenbach, R.P., Gschwend, P.M., Imboden, D.M., 2005. Sorption I: General 668 Introduction and Sorption Processes Involving Organic Matter. Environmental Organic 669 Chemistry. John Wiley \& Sons, Inc., pp. 275-330. 
670 Schwarzenbach, R.P., Westall, J., 1981. Transport of nonpolar organic compounds from

671 surface water to groundwater. Laboratory sorption studies. Environ. Sci. Technol. 15, 1360-

6721367.

673 Smedes, F., Geertsma, R.W., Zande, T.v.d., Booij, K., 2009. Polymer-Water Partition

674 Coefficients of Hydrophobic Compounds for Passive Sampling: Application of Cosolvent

675 Models for Validation. Environ. Sci. Technol. 43, 7047-7054.

676 Smedes, F., van Vliet, L.A., Booij, K., 2012. Multi-ratio equilibrium passive sampling

677 method to estimate accessible and pore water concentrations of polycyclic aromatic

678 hydrocarbons and polychlorinated biphenyls in sediment. Environ. Sci. Technol. 47, 510-517.

679 Smith, M.J., Flowers, T.H., Duncan, H.J., Saito, H., 2011. Study of PAH dissipation and

680 phytoremediation in soils: Comparing freshly spiked with weathered soil from a former

681 coking works. J. Hazard. Mater. 192, 1219-1225.

682 ten Hulscher, T.E.M., Postma, J., den Besten, P.J., Stroomberg, G.J., Belfroid, A., Wegener,

683 J.W., Faber, J.H., van der Pol, J.J.C., Hendriks, A.J., van Noort, P.C.M., 2003. Tenax

684 extraction mimics benthic and terrestrial bioavailability of organic compounds. Environ.

685 Toxicol. Chem. 22, 2258-2265.

686 Thorsen, W.A., Cope, W.G., Shea, D., 2004. Bioavailability of PAHs: Effects of Soot Carbon 687 and PAH Source. Environ. Sci. Technol. 38, 2029-2037.

688 Witt, G., Lang, S.-C., Ullmann, D., Schaffrath, G., Schulz-Bull, D., Mayer, P., 2013. Passive

689 equilibrium sampler for in situ measurements of freely dissolved concentrations of

690 hydrophobic organic chemicals in sediments. Environ. Sci. Technol. 47, 7830-7839.

691 Xia, H., Gomez-Eyles, J.L., Ghosh, U., 2016. Effect of Polycyclic Aromatic Hydrocarbon

692 Source Materials and Soil Components on Partitioning and Dermal Uptake. Environ. Sci.

693 Technol. 50, 3444-3452.

694 Zhang, Y., Pignatello, J.J., Tao, S., Xing, B., 2015. Bioacessibility of PAHs in Fuel Soot

695 Assessed by an in Vitro Digestive Model: Effect of Including an Absorptive Sink. Environ.

696 Sci. Technol. 49, 3905-3912.

697 


\section{$1 \quad$ Highlights}

2 - Sufficient passive sampling sorption capacity is crucial for quality assurance

$3 \quad-\quad$ Pollutant source type dominated $\mathrm{K}_{\mathrm{D}}$ and bioaccessible concentrations

4 - Lowest bioaccessible fractions (15\% on average) were found in skeet $5 \quad$ contaminated soils

6 - Petrogenic polluted soil had the highest bioaccessible fractions $(71 \%$ on 7 average)

8 